\title{
Measuring rates of gross photosynthesis and net community production in cryoconite holes: a comparison of field methods
}

\author{
J. TELLING, ${ }^{1}$ A.M. ANESIO, ${ }^{1}$ J. HAWKINGS, ${ }^{1}$ M. TRANTER, ${ }^{1}$ J.L. WADHAM, ${ }^{1}$ \\ A.J. HODSON, ${ }^{2}$ T. IRVINE-FYNN, ${ }^{2}$ M.L. YALLOP ${ }^{3}$ \\ ${ }^{1}$ Bristol Glaciology Centre, School of Geographical Sciences, University of Bristol, University Road, Bristol BS8 1SS, UK \\ E-mail: jon.telling@bristol.ac.uk \\ ${ }^{2}$ Department of Geography, University of Sheffield, Winter Street, Sheffield S10 2TN, UK \\ ${ }^{3}$ School of Biological Sciences, University of Bristol, Woodland Road, Bristol BS8 1UG, UK
}

\begin{abstract}
Photosynthesis by microbes on the surfaces of glaciers and ice sheets has the potential to fix carbon, alter the albedo of ice surfaces via the production of organic matter and so enhance ice melt. It could also be important for supplying labile organic matter and nutrients to in situ and downstream ecosystems. This study compares in situ 24 hour incubation methods for measuring rates of gross photosynthesis, respiration and net community production (NCP) in cryoconite holes on three Svalbard valley glaciers. Rates of gross photosynthesis and respiration measured by the $\Delta \mathrm{CO}_{2}$ method were closely balanced, resulting in rates of NCP close to the detection limit (mean of $-1.3 \mu \mathrm{g} \mathrm{C} \mathrm{g}^{-1} \mathrm{~d}^{-1}$ ) consistent with previous measurements in Arctic cryoconite holes. This suggests that organic matter within cryoconite holes may be derived largely from allochthonous sources. The molar ratio of $\Delta \mathrm{O}_{2}$ to $\Delta \mathrm{CO}_{2}$ in incubations gave mean respiratory and photosynthetic quotients of $0.80 \pm 0.17(1 \times \mathrm{SD})$ and $1.24 \pm 0.20(1 \times S D)$, respectively. The ${ }^{14} \mathrm{C}$ method typically underestimated rates of gross photosynthesis $\left(\triangle \mathrm{CO}_{2}\right.$ method) by more than one order of magnitude and measured a rate closer to NCP.
\end{abstract}

\section{INTRODUCTION}

The surfaces of glaciers and ice sheets are known to harbour a diverse range of prokaryotic and eukaryotic microorganisms (Mueller and others, 2001; Christner and others, 2003; Porazinska and others, 2004). The abundance and activity of the microorganisms is typically focused within thin sediment layers (cryoconite) found within shallow $(<50 \mathrm{~cm})$ waterfilled depressions known as cryoconite holes (Säwström and others, 2002; Hodson and others, 2007, 2008).

While rates of respiration and gross photosynthesis have been measured within cryoconite (Säwström and others, 2002; Hodson and others, 2007, 2010a,b; Stibal and others, 2008a; Anesio and others, 2009), there is current debate in the literature as to the balance between them. If respiration dominates and cryoconite holes are net heterotrophic, then the dominant source of organic carbon within cryoconite sediments must be allochthonous in origin (Stibal and others, 2008a; Hodson and others, 2010b). However, if rates of gross photosynthesis dominate, then the resultant net production of autochthonous organic matter could provide an important source of labile carbon and nutrients to in situ and downstream ecosystems (Anesio and others, 2009). Furthermore, the formation of autochthonous organic matter could potentially promote ice melting, either directly through the production of pigmented organic matter (Takeuchi and others, 2001; Mueller and Vincent, 2006) or indirectly by the entrapment of dark inorganic sediment by extracellular polymeric substances (Yallop and others, 1994; Stal, 2003; Mueller and Vincent, 2006).

To date, all studies that have measured in situ rates of photosynthesis in cryoconite holes have used closed-bottle incubations over either 12 or 24 hours (Säwström and others, 2002; Stibal and others, 2008a; Anesio and others, 2009; Hodson and others, 2010a,b). Only two studies have directly measured changes in $\mathrm{O}_{2}\left(\Delta \mathrm{O}_{2}\right)$ and $\mathrm{CO}_{2}\left(\Delta \mathrm{CO}_{2}\right)$ in the bottles (Hodson and others, 2010a,b), while the remainder have used the ${ }^{14} \mathrm{C}$ method originally developed by Steemann-Nielsen (1952). The ${ }^{14} \mathrm{C}$ method involves the addition of a small amount of $\mathrm{NaH}^{14} \mathrm{CO}_{3}$ as a tracer in closed-bottle incubations to measure rates of total C (i.e. ${ }^{12} \mathrm{C}$ ) uptake. Crucially, the ${ }^{14} \mathrm{C}$ method may underestimate the rate of gross photosynthesis due to recycling of ${ }^{14} \mathrm{CO}_{2}$ via cycles of photosynthesis and respiration (Peterson, 1980). Checking for these effects requires cross calibration with other methods (Bender and others, 1987).

This study uses in situ closed-bottle incubations in cryoconite holes on three Svalbard glaciers to cross calibrate the ${ }^{14} \mathrm{C}$ method against direct measurements of $\Delta \mathrm{CO}_{2}$ and $\Delta \mathrm{O}_{2}$.

\section{METHODS}

\section{Site location and descriptions}

Incubation experiments were conducted in 11 cryoconite holes on three valley glaciers, Midtre Lovénbreen (ML), Vestre Brøggerbreen (VB) and Austre Brøggerbreen (AB), situated in the northwest of the Svalbard archipelago, close to the scientific base at Ny-Ålesund $\left(78^{\circ} 55^{\prime} 48^{\prime \prime} \mathrm{N}\right.$, $11^{\circ} 56^{\prime} 59^{\prime \prime} \mathrm{E}$; Fig. 1). All incubations took place in July 2009. All the cryoconite holes studied were open, i.e. did not have ice lids. Owing to the relatively late start of the melt season on the glaciers in 2009, six of the 11 cryoconite holes were still covered in slush.

Cryoconite hole diameters, heights, water depths, slush depths and sediment depths were measured using a $30 \mathrm{~cm}$ ruler, to allow estimates of relative sediment-to-water volumes.

\section{$\mathrm{O}_{2}$, temperature and dissolved inorganic carbon} (DIC) measurements of water

Oxygen and temperature measurements were taken with a Hach HQ30d meter with luminescent dissolved oxygen 


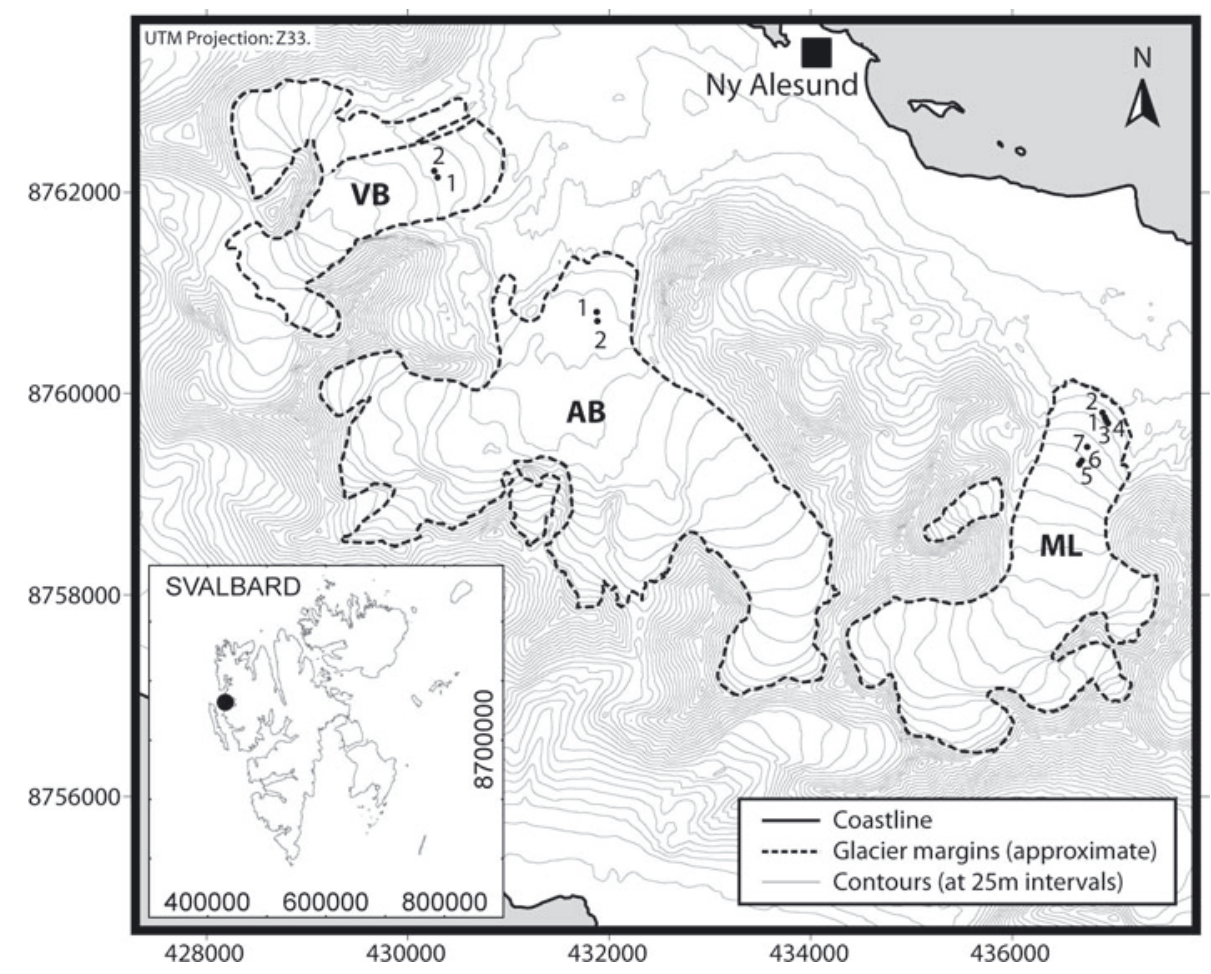

Fig. 1. Location of cryoconite holes where in situ rates of photosynthesis and respiration were measured. $A B=A$ Austre Brøggerbreen, $\mathrm{ML}=$ Midtre Lovénbreen, $\mathrm{VB}=$ Vestre Brøggerbreen. Note that $x$ and $y$ labels are in Universal Tranverse Mercator (UTM) coordinates.

probe following the method of Hodson and others (2010b). The relative standard deviation (RSD) of the luminescent oxygen probe was $1.5 \%$. The precision of the temperature sensor is quoted by the manufacturer as $\pm 0.1^{\circ} \mathrm{C}$. Measurements of DIC were made using a PP systems EGM-4 infrared $\mathrm{CO}_{2}$ meter, following the method of Hodson and others (2010b). The RSD was $0.98 \%$.

\section{Total organic carbon (TOC) content of cryoconite sediment}

Cryoconite was first dried at $70^{\circ} \mathrm{C}$ for 2 days then analysed for total carbon (TC) on a Eurovector EA3000 Elemental analyser. Inorganic carbon (IC) was determined using a Coulomat 720 analyser. TOC was defined as the difference between TC and $\mathrm{IC}$. The detection limit was $100 \mu \mathrm{g} \mathrm{Cg}^{-1}$ dry sediment.

\section{Batch incubations for estimating rates of photosynthesis and respiration}

\section{The $\Delta \mathrm{O}_{2}$ and $\Delta \mathrm{CO}_{2}$ methods}

At each site, sediment was collected from the hole and added to six glass bottles with tapered glass stoppers (60 mL BOD bottles, Wheaton) to give a sediment depth of $\sim 2-4 \mathrm{~mm}$. All bottles were filled completely with in situ supraglacial water to give approximate sediment/water ratios of $1: 60$. At each site, three of the bottles were chosen randomly and covered with aluminium foil (dark bottles). The remaining three bottles (light bottles) were illuminated by the natural levels found in situ. At three sites (one on each glacier), an additional two bottles (one light, one dark) were filled completely with supraglacial water only. All bottles were submerged completely in water within cryoconite holes and incubated for $24 \pm 2$ hours. If present, slush was scooped back over the bottles in the holes to give the same approximate depth of slush as was present initially.
Starting oxygen concentrations and temperature were measured on each individual bottle prior to incubation. Starting values for DIC were established by filling three identical BOD bottles with supraglacial water and measuring immediately for DIC, as described above. Oxygen, temperature and DIC were also measured in the bottles at the end of the incubation period. All measurements were made in situ on the glaciers immediately after removing the bottles from the cryoconite holes. Corrections for sulphide oxidation (for oxygen measurements, Equation (1)) and carbonate dissolution (for DIC measurements, Equation (2)) during incubation were made following the procedure of Hodson and others (2010b).

$$
\begin{gathered}
4 \mathrm{FeS}_{2}+15 \mathrm{O}_{2}+14 \mathrm{H}_{2} \mathrm{O} \rightarrow 8 \mathrm{SO}_{4}{ }^{2-}+4 \mathrm{Fe}(\mathrm{OH})_{3}+16 \mathrm{H}^{+} \\
\mathrm{CaMg}\left(\mathrm{CO}_{3}\right)_{2}+\mathrm{H}^{+} \rightarrow \mathrm{Ca}^{2+}+\mathrm{Mg}^{2+}=2 \mathrm{HCO}_{3}{ }^{-}
\end{gathered}
$$

Start and end incubation concentrations for $\mathrm{Ca}^{2+}, \mathrm{Mg}^{2+}$ and $\mathrm{SO}_{4}{ }^{2-}$ were measured on a Dionex 4000i Ion Chromatography System at the University of Bristol. The acidified samples were stored refrigerated for up to 4 months prior to analysis. The RSD for $\mathrm{Ca}^{2+}, \mathrm{Mg}^{2+}$ and $\mathrm{SO}_{4}{ }^{2-}$ determinations was $8.7 \%, 5.6 \%$ and $7.3 \%$, with corresponding detection limits of $2.0,0.93$ and $3.6 \mu \mathrm{M}$, respectively (based on mean $+(3 \times \mathrm{SD})$ of eight blanks $)$.

Total respiration and net community production (NCP) were determined from the $\mathrm{O}_{2}$ and DIC measurements in dark and light bottles, respectively. NCP is defined here as the net balance of gross photosynthesis and respiration for the entire microbial community. Gross photosynthesis rates were calculated by subtracting the $\mathrm{O}_{2}$ and DIC concentrations of dark bottles from light bottles. In all cases, rates were normalized for the different dry weights of sediment in the bottles, determined by drying and weighing the sediment. 
The detection limits for the $\Delta \mathrm{CO}_{2}$ method were $18 \mu \mathrm{gCL}^{-1} \mathrm{~d}^{-1}\left(1.2 \mu \mathrm{gCg}^{-1} \mathrm{~d}^{-1}\right)$ for rates of $\mathrm{NCP}$ and respiration, and $26 \mu \mathrm{gCL}^{-1} \mathrm{~d}^{-1}\left(1.7 \mu \mathrm{g} \mathrm{Cg}^{-1} \mathrm{~d}^{-1}\right)$ for gross photosynthesis. The detection limits for the $\Delta \mathrm{O}_{2}$ method were $96 \mu \mathrm{g} \mathrm{CL}^{-1} \mathrm{~d}^{-1}\left(6.2 \mu \mathrm{g} \mathrm{g} \mathrm{g}^{-1} \mathrm{~d}^{-1}\right)$ for rates of $\mathrm{NCP}$ and respiration and $136 \mu \mathrm{g} \mathrm{CL}^{-1} \mathrm{~d}^{-1}\left(8.8 \mu \mathrm{g} \mathrm{Cg}^{-1} \mathrm{~d}^{-1}\right)$ for gross photosynthesis. The sediment weight normalized detection limits assume $1 \mathrm{~g}$ of dry sediment, which was typical for the incubations of the present study.

\section{The ${ }^{14} \mathrm{C}$ method}

In parallel to the $\Delta \mathrm{O}_{2}$ and $\Delta \mathrm{CO}_{2}$ method incubations, sediment was added to six $7 \mathrm{~mL}$ transparent polystyrene vials with screw-cap lids to give sediment/volume ratios of approximately $1: 50$. All vials were glued horizontally to glass slides so they sank to the bottom of cryoconite holes, so that they received the same ambient light levels as the glass BOD bottle incubations used for the $\Delta \mathrm{CO}_{2}$ and $\Delta \mathrm{O}_{2}$ methods. Supraglacial water was then added to fill the vials completely, leaving no headspace. At three sites (one on each glacier), an additional two vials (one light, one dark) were filled completely with supraglacial water only. Aliquots $(7 \mu \mathrm{L})$ of a $37 \mathrm{MBq}$ stock of ${ }^{14} \mathrm{C}-\mathrm{NaHCO}_{3}$ (PerkinElmer) were added via an automatic pipette below the level of the water and the vials capped immediately. At each site, three of the six vials were covered with foil (dark controls) and the tubes left to incubate for $24 \pm 2$ hours. After incubation, samples were filtered immediately onto $0.2 \mu \mathrm{m}$ Nuclepore polycarbonate filters, the filtrates collected into $20 \mathrm{~mL}$ scintillation vials and $300 \mu \mathrm{L}$ of $3 \mathrm{M} \mathrm{HCl}$ added to acidify the samples and remove DIC. The filters were then transported back to the laboratory within 4 hours and left under an upturned beaker in a fume cupboard for 1 hour with small open beakers of $25 \%$ glutaraldehyde and concentrated hydrochloric acid to kill microbial activity and remove DIC. The filters were next placed in preweighed scintillation vials, allowed to dry overnight at $70^{\circ} \mathrm{C}$ and reweighed. The acidified filtrates were shaken and left to degas overnight in the fume cupboard. Samples were transported in $20 \mathrm{~mL}$ scintillation vials back to the UK, then $5 \mathrm{~mL}$ aliquots of scintillation cocktail (Ultima Gold ${ }^{\mathrm{TM}}$, PerkinElmer) were added to $1 \mathrm{~mL}$ aliquots of filtrates, and $10 \mathrm{~mL}$ of scintillation cocktail added to filters. The vials were then left in the dark for 24 hours prior to counting on a PerkinElmer Tri-Carb 2810 TR scintillation counter, using external standards to correct for quenching.

DPM values were converted to carbon uptake values by:

$$
{ }^{12} \mathrm{C} \text { uptake }=\frac{{ }^{14} \mathrm{C} \text { sample } \times \mathrm{C} \times 1.06}{{ }^{14} \mathrm{C} \text { added } \times t},
$$

where ${ }^{12} \mathrm{C}$ uptake is the amount of carbon taken up into cells ( $\mu \mathrm{C} \mathrm{CL}^{-1} \mathrm{~d}^{-1}$ ), ${ }^{14} \mathrm{C}$ sample is the activity of the sample (sum of filtrate and filter DPMs), C is the concentration of DIC in the incubation water $\left(\mu \mathrm{g} \mathrm{CL}{ }^{-1}\right), 1.06$ is the isotope constant effect between ${ }^{12} \mathrm{C}$ and ${ }^{14} \mathrm{C},{ }^{14} \mathrm{C}$ added is the activity of $\mathrm{NaH}^{14} \mathrm{CO}_{3}$ added to each vial (DPM) and $t$ is the duration of incubation (days).

Rates of photosynthesis were calculated by subtracting dark control from light bottle incubations. The percentage of ${ }^{14} \mathrm{C}$ incorporated into extracellular dissolved organic material $\left({ }^{14} \mathrm{C}-\mathrm{DOC}\right)$, rather than into microbial cells or particulate matter, was defined as the percentage of the ${ }^{14} \mathrm{C}$ measured in the filtrates compared with that on the filters.

\section{Statistical analysis}

Preliminary statistical tests (for normality and variance) were carried out using the SPSS statistical software package. These tests demonstrated that the ${ }^{14} \mathrm{C}, \Delta \mathrm{CO}_{2}$ and $\Delta \mathrm{O}_{2}$ datasets had approximately normal distributions; however, there were differences in variance between methods. Consequently, comparisons between methods were carried out using two-tailed $t$ tests $(p<0.05)$ assuming non-equal variances. Correlations were carried out using Pearson's product-moment correlation method.

\section{RESULTS}

\section{Temperature, $\mathrm{O}_{2}$ saturation and DIC of in situ cryoconite water}

The temperature of the water in all 11 cryoconite holes used for incubation experiments was $0.1 \pm 0.1^{\circ} \mathrm{C} . \mathrm{O}_{2}$ saturation levels were $100 \pm 4.6 \%$ and DIC concentrations ranged from 29.8 to $44.9 \mu \mathrm{M}$ (Table 1).

\section{Temperature, calcium, magnesium and sulphate changes in incubation water}

There was no systematic difference in temperature between light and dark incubations of the $\Delta \mathrm{O}_{2}$ and $\Delta \mathrm{CO}_{2}$ methods, with a mean difference of $0.0 \pm 0.7^{\circ} \mathrm{C}(1 \times \mathrm{SD})$. The mean temperatures measured at the start and end of incubations were $2.1^{\circ} \mathrm{C}\left( \pm 1.1^{\circ} \mathrm{C}, 1 \times \mathrm{SD}\right)$ and $1.3^{\circ} \mathrm{C}\left( \pm 0.7^{\circ} \mathrm{C}, 1 \times \mathrm{SD}\right)$, respectively, slightly higher than the mean in situ temperature of $0.1{ }^{\circ} \mathrm{C}$. However, temperatures in incubations were measured after bottles had been removed from the cryoconite holes and oxygen measurements taken. The warmer temperatures could therefore be an artefact of shortterm surface warming during measurements rather than representative of incubation temperatures.

The maximum changes in $\mathrm{Ca}^{2+}$ and $\mathrm{Mg}^{2+}$ during incubations were $<6$ and $<2 \mu \mathrm{M}$, respectively, with the exception of $\mathrm{AB} 1$ incubations where the $\mathrm{Ca}^{2+}$ and $\mathrm{Mg}^{2+}$ changes measured were up to 31 and $18 \mu \mathrm{M}$, respectively. No changes in $\mathrm{SO}_{4}{ }^{2-}$ concentration during incubations were detected.

\section{TOC content of cryoconite}

The TOC content of cryoconite ranged from 14 to $32 \mathrm{mg}$ $\mathrm{Cg}^{-1}$ dry sediment, with an average of $23 \mathrm{mg} \mathrm{Cg}^{-1}$ dry sediment $\mathrm{d}^{-1}$ (Table 1).

\section{Comparison of $\Delta \mathrm{O}_{2}$ and $\Delta \mathrm{CO}_{2}$ methods for respiration and gross photosynthesis and NCP}

Rates of gross photosynthesis and respiration determined by the $\Delta \mathrm{CO}_{2}$ method in cryoconite-amended incubations were of similar magnitude $\left(6.5-32.2 \mu \mathrm{g} \mathrm{Cg}^{-1} \mathrm{~d}^{-1}\right.$ for gross photosynthesis, $4.3-37.1 \mu \mathrm{g} \mathrm{Cg}^{-1} \mathrm{~d}^{-1}$ for respiration; Table 2), resulting in relatively small changes in NCP (-11.9 to $8.0 \mu \mathrm{g} \mathrm{g} \mathrm{g}^{-1} \mathrm{~d}^{-1}$; Table 2). A comparison of paired $\Delta \mathrm{O}_{2}$ and $\Delta \mathrm{CO}_{2}$ rates of gross photosynthesis, respiration and NCP is shown in Figure 2. For all paired measurements above the detection limit (Fig. 2), the mean photosynthetic quotient ( $\mathrm{PQ}$, the molar ratio of $\mathrm{O}_{2}$ produced to $\mathrm{CO}_{2}$ consumed) was $1.24 \pm 0.20(1 \times \mathrm{SD})$. The mean respiratory quotient $(\mathrm{RQ}$, the molar ratio of $\mathrm{CO}_{2}$ produced to $\mathrm{O}_{2}$ consumed) was $0.80 \pm 0.17(1 \times \mathrm{SD})$. The mean NCP quotient (defined here as the molar ratio of $\mathrm{O}_{2}$ produced to $\mathrm{CO}_{2}$ consumed) was $2.34 \pm 1.90(1 \times \mathrm{SD})$. There were significant differences between paired $\Delta \mathrm{O}_{2}$ and $\Delta \mathrm{CO}_{2}$ measurements for 
Table 1. Physical and chemical characteristics of cryoconite holes

\begin{tabular}{|c|c|c|c|c|c|c|c|c|c|}
\hline Site & $\begin{array}{l}\text { Date of incubation } \\
\qquad(2009)\end{array}$ & $\begin{array}{l}\text { Average } \\
\text { depth of } \\
\text { sediment }\end{array}$ & $\begin{array}{l}\text { Depth of } \\
\text { water }\end{array}$ & $\begin{array}{c}\text { Area of } \\
\text { cryoconite }\end{array}$ & $\begin{array}{l}\text { Water volume/ } \\
\text { sediment volume }\end{array}$ & $\begin{array}{c}\text { Slush depth } \\
\text { above } \\
\text { cryoconite hole }\end{array}$ & DIC & Oxygen & $\begin{array}{c}\text { Organic } \\
\text { carbon } \\
\text { content }\end{array}$ \\
\hline & & $\mathrm{mm}$ & $\mathrm{cm}$ & $\mathrm{cm}^{2}$ & & $\mathrm{~cm}$ & $\mu \mathrm{M}$ & $\%$ saturation & $\mathrm{mgCg}^{-1}$ \\
\hline ML 1 & 8-9 July & 3 & 2.0 & 132.1 & 6 & 0.0 & 40.2 & 98.6 & 21.9 \\
\hline ML 2 & 8-9 July & 1 & 6.0 & 43.5 & 60 & 0.0 & 29.8 & 99.0 & 21.5 \\
\hline ML 3 & 10-11 July & 1 & 4.0 & 51.4 & 40 & 10.0 & 30.6 & 100.9 & 26.1 \\
\hline ML 4 & 10-11 July & 3 & 12.0 & 51.4 & 40 & 17.5 & 29.9 & 100.6 & 14.0 \\
\hline ML 5 & 23-24 July & 3 & 3.0 & 118.7 & 9 & 0.0 & 31.7 & 104.6 & 28.6 \\
\hline ML 6 & 23-24 July & 3 & 5.5 & 63.3 & 18 & 0.0 & 33.9 & 103.7 & 22.8 \\
\hline ML 7 & 23-24 July & 2 & 10.0 & 43.5 & 50 & 0.0 & 30.8 & 103.4 & 25.8 \\
\hline VB 1 & 17-18 July & 2 & 15.0 & 47.5 & 75 & 5.0 & 44.9 & 102.0 & 32.3 \\
\hline VB 2 & 17-18 July & 2 & 8.0 & 73.6 & 40 & 9.0 & 35.5 & 99.2 & 23.9 \\
\hline $\mathrm{AB} 1$ & 21-22 July & 2 & 5.5 & 49.0 & 28 & 9.0 & 33.3 & 103.1 & 12.7 \\
\hline
\end{tabular}

Note: $\mathrm{ML}=$ Midtre Lovénbreen; $\mathrm{VB}=$ Vestre Brøggerbreen; $\mathrm{AB}=$ Austre Brøggerbreen.

photosynthesis $(p<0.05$, two-tailed $t$ test $)$ and gross photosynthesis $(p<0.05$, two-tailed $t$ test), but not for NCP ( $p=0.27$, two-tailed $t$ test).

Rates of gross photosynthesis and respiration were substantially lower in the water-only incubations compared with cryoconite-amended incubations (Table 2). Mean rates of respiration and gross photosynthesis in water-only incubations were 7.39 and $85.6 \mu \mathrm{g} \mathrm{CL}^{-1} \mathrm{~d}^{-1}$, respectively $\left(\Delta \mathrm{CO}_{2}\right.$ method) (Table 2). In situ ratios of cryoconite:water in the cryoconite holes (mean $1: 34$, range from $1: 6$ to $1: 75$; Table 1) were generally similar to, or lower than, that of the incubation bottles $(1: 60)$. Rates of gross photosynthesis and respiration measured in bottle incubations should therefore approximate in situ rates of cryoconite holes.

The daily rates of gross photosynthesis were sufficient to utilize $41-291 \%$ (mean 146\%) of the starting DIC pool in incubation bottles (Table 2). Since rates of NCP demonstrate only relatively small changes in DIC over the course of the incubations (Table 2; Fig. 3), this indicates that the DIC pool in incubation bottles is typically recycled completely in 24 hours. In contrast, daily rates of gross photosynthesis in water-only incubations were only capable of utilizing $0.5-1.9 \%$ (mean $1.2 \%$ ) of the starting DIC pool (Table 2).

\section{Comparison of the ${ }^{14} \mathrm{C}$ method with estimates of NCP and gross photosynthesis by the $\Delta \mathrm{CO}_{2}$ method}

Measurements of photosynthesis by the ${ }^{14} \mathrm{C}$ method ranged from 0.3 to $3.9 \mu \mathrm{g} \mathrm{Cg}^{-1} \mathrm{~d}^{-1}$ (Table 2). These are closer to rates of NCP rather than gross photosynthesis as determined by the $\Delta \mathrm{CO}_{2}$ method (Fig. 3). There were significant differences between mean rates of ${ }^{14} \mathrm{C}$ photosynthesis and gross photosynthesis $(p<0.05$, two-tailed $t$ test), but not between ${ }^{14} \mathrm{C}$ photosynthesis and NCP ( $p=0.186$, two-tailed $t$ test). Paired rates of ${ }^{14} \mathrm{C}$ photosynthesis with $\mathrm{NCP}$ and paired rates of ${ }^{14} \mathrm{C}$ photosynthesis with gross photosynthesis were poorly positively correlated $(R=0.57$ and 0.53 , respectively), with neither correlation significantly different from zero $(p<0.05)$ (Fig. 4).

Table 2. Rates of gross photosynthesis, respiration, NCP (all from $\Delta \mathrm{CO}_{2}$ method) and ${ }^{14} \mathrm{C}$ photosynthesis in cryoconite sediment and water incubations. Mean rates are shown with minimum and maximum rates in parentheses. Negative numbers for NCP indicate net heterotrophy; positive numbers indicate net autotrophy

Sediment and water ( $n=11$ triplicate samples)

$\mu \mathrm{g} C \mathrm{~g}^{-1} \mathrm{~d}^{-1}$

$\mu g \mathrm{CL}^{-1} \mathrm{~d}^{-1}$
Water only ( $n=3$ single samples) $\mu \mathrm{gCL} L^{-1} \mathrm{~d}^{-1}$
Gross photosynthesis

$\Delta \mathrm{CO}_{2}$ method

$\%$ gross photosynthesis of starting DIC pool*

Respiration

$\Delta \mathrm{CO}_{2}$ method

Net photosynthesis

$\Delta \mathrm{CO}_{2}$ method

${ }^{14} \mathrm{C}$ method

Photosynthesis

$\%{ }^{14} \mathrm{C}$ dark bottle of light bottle

$\%{ }^{14} \mathrm{C}$ fixed in DOC fraction
$500(254-807)$

$20.1(4.3-37.1)$

$-1.3(-11.9$ to 8.0$)$

$1.2(0.3-3.9)$

$8.0(2.6-15.8)$

$0.75(0.2-1.4)$
$7.4(2.6-12.2)$

$1.2(0.5-1.9)$

$85.6(25.1-146.0)$

$-78.2(22.5-134.0)$

$0.2(0.1-0.3)$

$21.9(11.1-32.8)$

$26.8(13.0-37.3)$

*The percentage of the starting DIC pool that is used in a day by the measured rates of gross photosynthesis $\left(\Delta \mathrm{CO}_{2} \mathrm{method}\right)$. 

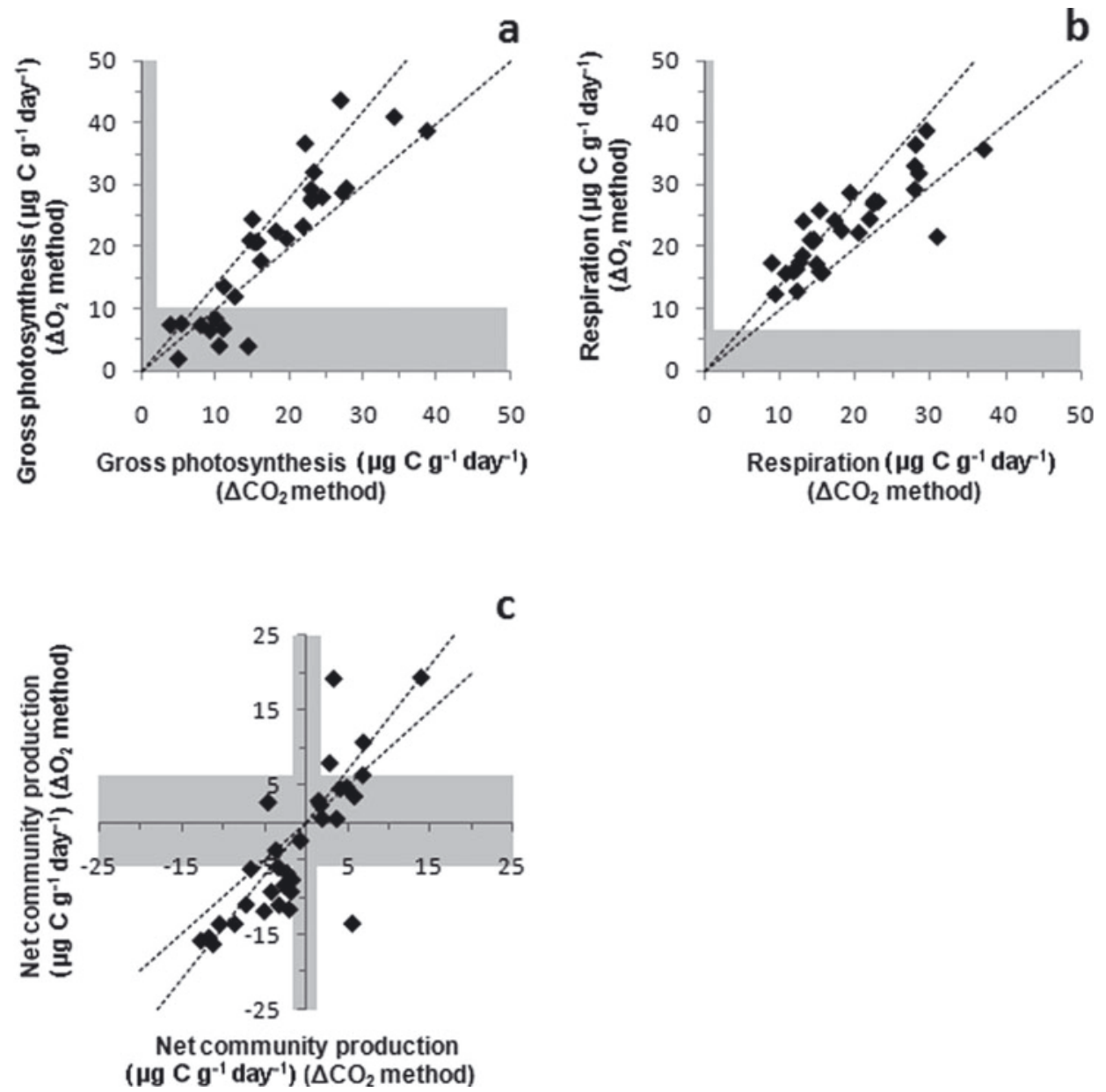

Fig. 2. Comparison of paired measurements of rates by $\mathrm{CO}_{2}$ and $\mathrm{O}_{2}$ methods. (a) Gross photosynthesis, (b) respiration and (c) NCP. Dotted lines show typical ranges of photosynthetic and respiratory quotients (PQ and RQ) from other environments: PQ range of 1.0-1.4 (Williams and Robertson, 1991); RQ range of 0.7-1.0 (Gnaiger, 1983). Shaded areas are below the detection limit.
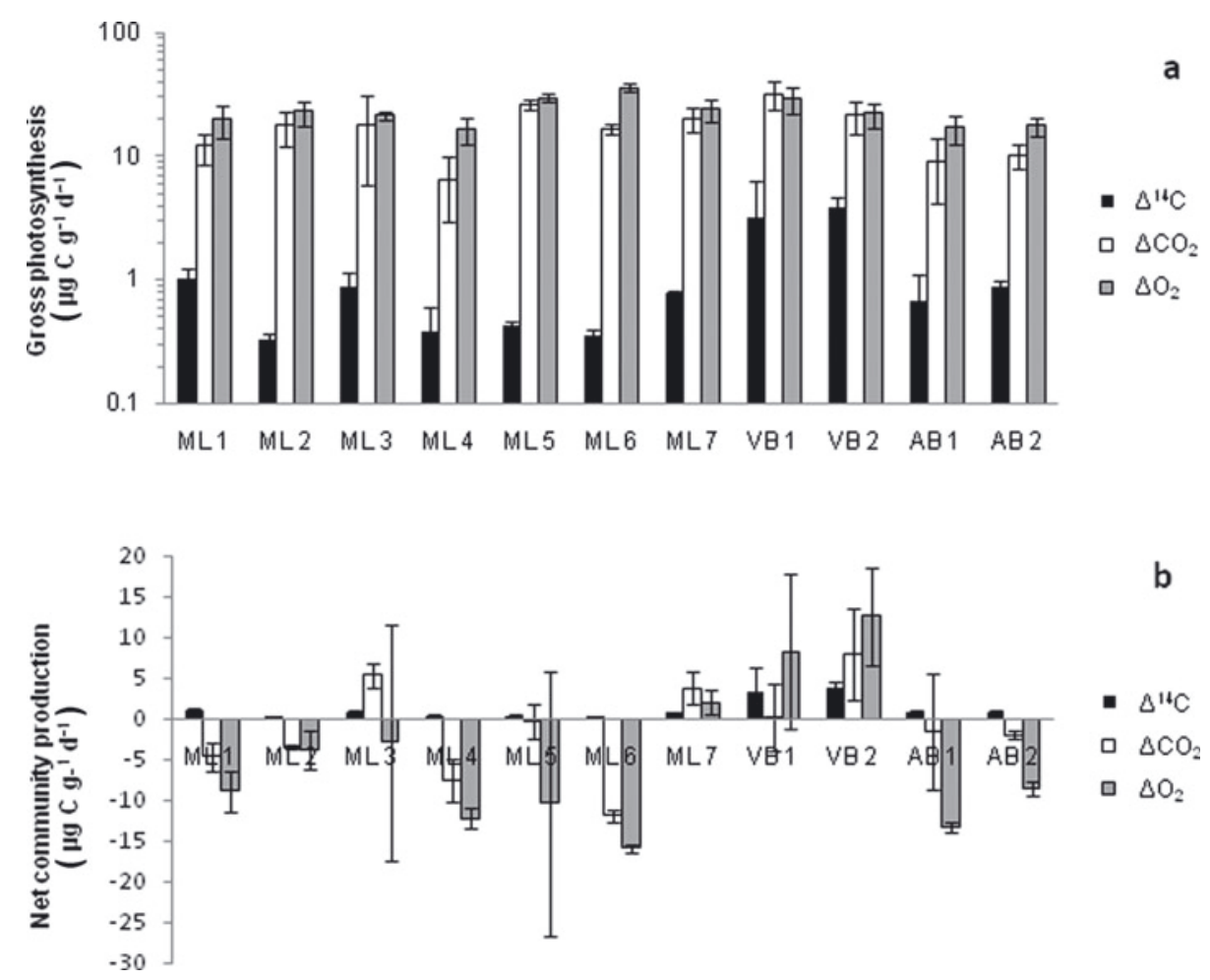

Fig. 3. Comparison of rates of photosynthesis by ${ }^{14} \mathrm{C}$ method with (a) rates of gross photosynthesis by the $\Delta \mathrm{O}_{2}$ and $\Delta \mathrm{CO}_{2}$ methods and (b) rates of NCP by the $\Delta \mathrm{O}_{2}$ and $\Delta \mathrm{CO}_{2}$ methods. Error bars are $1 \mathrm{SD}$. Note the logarithmic scale in (a). 

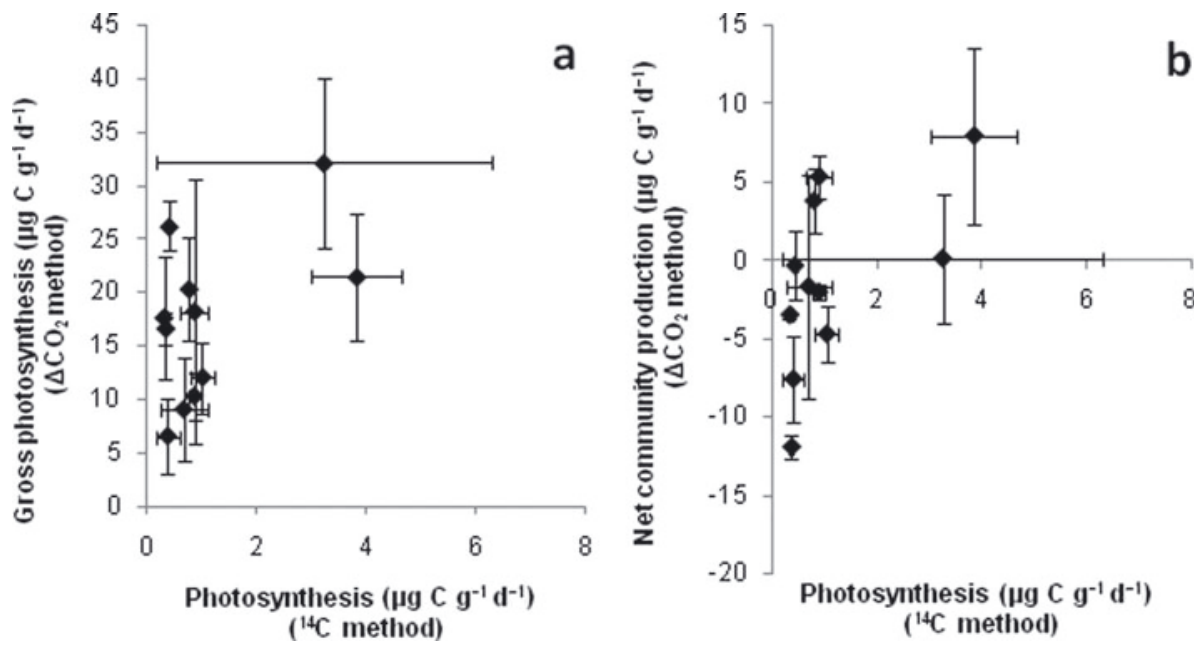

Fig. 4. Scatter plots of rates of photosynthesis measured by the ${ }^{14} \mathrm{C}$ method vs (a) gross photosynthesis $\left(\Delta \mathrm{CO}_{2}\right.$ method) and (b) $\mathrm{NCP}\left(\Delta \mathrm{CO}{ }_{2}\right.$ method). Errors bars are $1 \mathrm{SD}$ of triplicate measurements. Pearson's product-moment correlation indicated no significant relationships $(p<0.05)$ in either (a) or (b).

\section{Dark bottle uptake of ${ }^{14} \mathrm{C}$ and percentage of ${ }^{14} \mathrm{C}$ released as dissolved organic matter}

There was a significant uptake of ${ }^{14} \mathrm{C}$ in dark bottles, with higher rates in water-only incubations $(11-33 \%$, mean $22 \%$; Table 2) compared with sediment-amended incubations (2.6-16.0\%, mean $8.0 \%$; Table 2). The percentage of ${ }^{14} \mathrm{C}$ released as ${ }^{14} \mathrm{C}$-DOC into the filtrate fraction of sedimentamended incubations was low (0.2-1.4\%; Table 2). A larger percentage of ${ }^{14} \mathrm{C}$-DOC was measured in the filtrate fraction of water-only incubations (13.0-37.3\%).

\section{DISCUSSION}

\section{Respiratory and photosynthetic quotients (RQ and PQ) in Arctic cryoconite holes}

The sediment fraction of cryoconite holes in the present study dominates both rates of gross photosynthesis and respiration (Table 2). This is consistent with previous studies on Arctic cryoconite holes (Säwström and others, 2002; Anesio and others, 2009; Hodson and others, 2010b). Previous studies have also assumed a 1:1 stoichiometry between $\Delta \mathrm{O}_{2}$ and $\Delta \mathrm{CO}_{2}$ in Arctic cryoconite holes (Hodson and others, 2007; Anesio and others, 2009). However, the present study demonstrated that there were significant differences $(p<0.05)$ between the $\Delta \mathrm{O}_{2}$ and $\Delta \mathrm{CO}_{2}$ methods for measuring rates of respiration and gross photosynthesis, resulting in a mean RQ of $0.88 \pm 0.17$ $(1 \times \mathrm{SD})$ and a mean PQ of $1.24 \pm 0.2(1 \times \mathrm{SD})($ Fig. 2$)$. The mean $R Q$ is within the range of $R Q$ values expected from variations in the composition of biological organic matter (0.7-1.0; Gnaiger, 1983). Similarly, the mean PQ value of the present study is within the typical PQ range for algae (1.0-1.4; Williams and Robertson, 1991), with PQ varying with the source of nitrogen (e.g. ammonia or nitrate) used by the photosynthetic cells (Williams and Robertson, 1991).

\section{Rates of gross photosynthesis in cryoconite holes}

The rates of gross photosynthesis in cryoconite-amended incubations (mean of $17.3 \mu \mathrm{g} \mathrm{Cg}^{-1} \mathrm{~d}^{-1}$ by the $\Delta \mathrm{CO}_{2}$ method) are similar to previous estimates of gross photosynthesis in Arctic cryoconite holes in Svalbard and Greenland made using the same method (mean between 15.7 and $23 \mu \mathrm{g} \mathrm{g} \mathrm{g}^{-1} \mathrm{~d}^{-1}$, respectively; Hodson and others 2010a,b; Table 3). The factors limiting rates of gross photosynthesis in cryoconite holes have yet to be established, although phosphorus has been suggested as a likely limiting factor on rates of overall microbial growth (Säwström and others, 2007a; Stibal and others, 2008b).

The average rates of gross photosynthesis from the only available data of Antarctic cryoconite holes are an order of magnitude lower than Arctic cryoconite holes at $2.4 \mu \mathrm{g} \mathrm{C} \mathrm{g}{ }^{-1} \mathrm{~d}^{-1}$ (Hodson and others, 2010b; Table 3). This could reflect the closed more hydrologically isolated nature of Antarctic cryoconite holes due to the thick ice lids that commonly form above them (Tranter and others, 2004). Greater isolation both from the atmosphere and from hydrological flow would reduce the flux of both DIC and nutrients (Tranter and others, 2004), while the thicker ice lids may lower the levels of light available to microorganisms.

\section{The potential problem of bottle effects}

This study assumes that rates of photosynthesis and respiration measured within incubation bottles accurately reflect those of the in situ cryoconite holes. However, there remains the possibility that nutrient concentrations in the bottles could change over 24 hours from in situ concentrations. This could potentially alter both rates of microbial processes and community structure in the bottles (i.e. 'bottle effects'; Li and Dickie, 1991). Ideally, future studies of cryoconite holes should compare shorter-term measurements of photosynthesis and respiration with 24 hour measurements to check for any bottle effects.

A further assumption of the light-dark bottle technique for estimating rates of gross photosynthesis is that rates of respiration are the same in the dark bottles as in the light bottles. Previous studies on other aquatic environments have shown that, while often true, this is not always the case and that respiration rates in the light can be higher than in the dark, leading to an underestimation of gross rates of photosynthesis (Yallop, 1982; Bender and others, 1987; Kana, 1990). Processes that can cause increased respiration in light bottles include photorespiration and the Mehler reaction involving uptake of oxygen by photosystem 1 
Table 3. Summary of published rates of gross photosynthesis, NCP and ${ }^{14} \mathrm{C}$ photosynthesis in cryoconite holes

\begin{tabular}{lccc}
\hline Method, study site & $\begin{array}{c}\text { Gross photosynthesis } \\
\mu g \mathrm{Cg}^{-1} \mathrm{~d}^{-1}\end{array}$ & $\begin{array}{c}{ }^{14} \mathrm{C}_{\text {photosynthesis }} \\
\mu \mathrm{g} \mathrm{g}^{-1} \mathrm{~d}^{-1}\end{array}$ & $\mu \mathrm{g} \mathrm{g}^{-1} \mathrm{~d}^{-1}$ \\
\hline
\end{tabular}

$\triangle \mathrm{CO}_{2}$ method

Svalbard:

$M L, A B, V B$

Longyearbyen

$17.3(6.5-32.2)$

$23.0(4.2-35.8)^{\dagger}$

$-1.3(-11.9-8.0)$

$-0.6(-7.1-2.8)^{\dagger}$

$22.4(1.3-40.8)^{\dagger}$

$15.6(0.1-28.7) \quad-1.8(-10.0-1.3)$

$2.4(0.7-9.3)^{\dagger}$

East Antarctica ice sheet

\author{
This study \\ Hodson and others (2010b) \\ Hodson and others (2010b) \\ Hodson and others (2010a)
}

Hodson and others (2010b)

This study

Svalbard:

$M L, A B, V B$

Werenskioldbreen

Werenskioldbreen (laboratory study)

\author{
$1.2(0.3-3.9)$ \\ $0.290(0.096-0.480)^{*}$ \\ $0.1-3.6^{\S}$
}

Stibal and others (2008a)

Stibal and Tranter (2007)

Note: $\mathrm{ML}=$ Midtre Lovénbreen; $\mathrm{VB}=$ Vestre Brøggerbreen; $\mathrm{AB}=$ Austre Brøggerbreen.

*The ${ }^{14} \mathrm{C}$ results of Säwström and others (2002) are not included as results were only reported in $\mu \mathrm{C} \mathrm{L} \mathrm{L}^{-1} \mathrm{~d}^{-1}$ with no sediment weights to allow conversion to $\mu \mathrm{g} \mathrm{C} \mathrm{g}{ }^{-1} \mathrm{~d}^{-1}$. The ${ }^{14} \mathrm{C}$ results of Anesio and others (2009) are not included as the incubation methods used (use of plastic bags in incubations rather than gastight BOD bottles, inappropriate sediment/water ratios, and incubation at the surface rather than submerged in cryoconite holes, allowing greater incident light and warmer temperatures) were not as realistic as those in the studies included.

These rates are ten times lower than the values published originally, due to an initial error in calculation.

*These rates potentially could have been up to three times higher due to the use of a headspace within the ${ }^{14} \mathrm{C}$ incubations. They were also converted from wet to dry weights by assuming a dry/wet weight of $1: 2$.

${ }^{\S}$ The ${ }^{14} \mathrm{C}$ rates of Stibal and Tranter (2007) may have overestimated in situ rates of net photosynthesis due to the use of shorter incubation times, different pHs and warmer incubation temperatures.

(Burris, 1977; Yallop, 1982; Lancelot and Mathot, 1985). Conversely, respiration rates in the light could be lower than in the dark, either due to differences in temperature within dark and light bottles or inhibition of microorganisms by ultraviolet (UV) radiation (Thomson and others, 1980; Herndl and others, 1993). The former can be discounted, as there were no systematic temperature differences between paired light and dark bottles in the present study. Inhibition by UV radiation is also unlikely to reduce rates of respiration, since the glass walls of the incubation bottles used for the $\Delta \mathrm{CO}_{2}$ and $\Delta \mathrm{O}_{2}$ methods will cut out the majority of harmful UV-B radiation (Ferreyra and others, 1997).

However, it is possible that the elimination of UV-B radiation in glass bottle incubations may have artificially increased rates of photosynthesis and respiration in the $\Delta \mathrm{CO}_{2}$ and $\Delta \mathrm{O}_{2}$ methods relative to in situ rates (Cullen and others, 1992; Herndl and others, 1993). In contrast to the glass bottles, the polystyrene vials used in the ${ }^{14} \mathrm{C}$ method will have transmitted a significant fraction of the UV-B spectrum (Furgal and Smith, 1997).

\section{Uncertainties in interpreting the ${ }^{14} \mathrm{C}$ results}

Importantly, this study has shown that ${ }^{14} \mathrm{C}$ measurements do not accurately measure rates of either gross photosynthesis or NCP in cryoconite holes (Fig. 4). However, rates of ${ }^{14} \mathrm{C}$ photosynthesis are closer to those of NCP than gross photosynthesis (Fig. 3). The majority of aqueous ecological studies that have used the ${ }^{14} \mathrm{C}$ method over 24 hours have concluded that it measures a rate closer to net photosynthesis rather than gross photosynthesis (Peterson, 1980; Dring and Jewson, 1982; Behrenfeld and Falkowski, 1997). Net photosynthesis is defined here as gross photosynthesis minus photoautotrophic respiration, in contrast to NCP which subtracts total community respiration (Peterson, 1980). The model most commonly used to explain why the ${ }^{14} \mathrm{C}$ method can measure a rate closer to net photosynthesis is that of Hobson and others (1976). In this model, photosynthetically fixed ${ }^{14} \mathrm{C}$-organic matter is respired back to ${ }^{14} \mathrm{CO}_{2}$ and exuded outside the cell. The initial rate of photosynthesis will be closer to gross rates of photosynthesis because the initial organic matter within the cell will be low in ${ }^{14} \mathrm{C}$, so respiration will initially remove little ${ }^{14} \mathrm{C}$. As incubation time increases, the ${ }^{14} \mathrm{C}$ content of the cell organic matter increases, so that the relative loss of ${ }^{14} \mathrm{C}$ back to ${ }^{14} \mathrm{CO}_{2}$ will also increase, until rates eventually approach that of net photosynthesis (Hobson and others, 1976; Williams and Lefèvre, 2008).

The model of Hobson and others (1976) assumes that photoautotrophic respiration is responsible for all the respiration of photosynthetically fixed ${ }^{14} \mathrm{C}$-organic matter. However, if heterotrophic microorganisms respire a significant fraction of the fixed ${ }^{14} \mathrm{C}$-organic matter, then the ${ }^{14} \mathrm{C}$ method can potentially measure a rate lower than net photosynthesis and approach NCP (Gieskes and others, 1979). In net heterotrophic ecosystems, however, the ${ }^{14} \mathrm{C}$ method can only approach zero rather than NCP, as an intrinsic drawback of the ${ }^{14} \mathrm{C}$ method is that it can only measure positive (i.e. net autotrophic) values (Peterson, 1980).

There was significant heterotrophic activity within the incubations of the present study. Indeed, many of the incubations were net heterotrophic (Fig. 3), although the proportion of heterotrophic to photoautotrophic respiration in the cryoconite is not known (Anesio and others, 2010). Furthermore, the dark ${ }^{14} \mathrm{C}$ uptake results of the present study were consistent with substantial heterotrophic activity. The mean dark ${ }^{14} \mathrm{C}$ uptakes of $8.0 \%$ and $21.9 \%$ (for 
sediment-amended and water-only incubations, respectively; Table 2) were of a similar magnitude to those reported previously in Svalbard cryoconite $(6.4-16.0 \%$; Stibal and Tranter, 2007) and higher than the $1-2 \%$ typically found in surface ocean water ( $\mathrm{Li}$ and others, 1993). Such relatively high dark uptake of ${ }^{14} \mathrm{C}$ has previously been interpreted as the results of a high proportion of heterotrophic to photoautotrophic respiration (Gieskes and others, 1979). However, other autotrophic bacteria (in particular, ammonia-oxidizing bacteria) could also be responsible for part of the dark ${ }^{14} \mathrm{C}$ uptake (Billen, 1976).

Heterotrophic microorganisms need to gain access to, and respire, the photosynthetically fixed ${ }^{14} \mathrm{C}$-organic matter in order to directly affect the results of the ${ }^{14} \mathrm{C}$ method. The principal mechanisms for this are cell lysis (and promotion of cell lysis by viral infection), grazing by predators (Karl and others, 1998) and the release of organic matter from photosynthetic cells by passive or active exudation (Fogg, 1983). While rates of cell lysis in cryoconite holes are unknown, the virus-induced lysis of cells in cryoconite holes may be an important source of organic carbon for heterotrophic microorganisms (Anesio and others, 2007; Säwström and others, 2007b). A high incidence of microbial infection by phage cells has also been reported in cryoconite waters on ML (Säwström and others, 2007b) and high ratios of viruses to bacteria have been documented in cryoconite sediments and waters on $\mathrm{AB}$ and $\mathrm{ML}$ (Anesio and others, 2007). In addition, eukaryotic predatory microorganisms, including tardigrades, rotifers and ciliates, have been documented in cryoconite holes (De Smet and Van Rompu, 1994; Porazinska and others, 2004), although the ecological importance of grazing in cryoconite holes has yet to be established. However, over the timescale of incubations in our study, the exudation of dissolved or colloidal organic matter by living photosynthetic algae and cyanobacteria is likely to be more important as a source of organic matter for heterotrophic microorganisms than cell lysis or grazing (Karl and others, 1998).

The percentages of ${ }^{14} \mathrm{C}$ exuded as DOC in water-only incubations of the present study (13.0-37.3\%; Table 2) were similar to those in other aquatic environments (typically 5-40\%; Fogg, 1983; Baines and Pace, 1991; Morán and others, 2002), whereas cryoconite-amended incubations had relatively low percentages of ${ }^{14} \mathrm{C}$-DOC (0.2-1.4\%; Table 2). However, in microbial mats in some benthic environments, as much as $70 \%$ of total primary production may be exuded as colloidal organic matter in the form of extracellular polysaccharides (EPS) (Stal, 1993; Goto and others, 1999). The relatively low percentages of ${ }^{14} \mathrm{C}$-DOC in sediment incubations of the present study could therefore be explained by the exudation of colloidal ${ }^{14} \mathrm{C}$-organic matter. Certainly, the production of colloidal EPS is consistent with a study indicating that cyanobacteria in cryoconite bind granules together with EPS (Hodson and others, 2010b). Alternatively, however, the relatively low ${ }^{14} \mathrm{C}$-DOC percentages could reflect either an overall low rate of organic matter exudation, or an efficient uptake of exuded ${ }^{14} \mathrm{C}$-DOC by heterotrophic bacteria in the cryoconite-amended incubations (Karl and others, 1998). Further research is needed to distinguish between these hypotheses.

Interpreting the ecological significance of the ${ }^{14} \mathrm{C}$ method in the present study is therefore problematic. If the bulk of photosynthetically fixed ${ }^{14} \mathrm{C}$-organic matter was respired by the photosynthetic microorganisms rather than heterotrophic microorganisms, then the 24 hour ${ }^{14} \mathrm{C}$ method could have measured a rate close to that of net photosynthesis. If, however, heterotrophic recycling was substantial, then the ${ }^{14} \mathrm{C}$ method may have measured a rate in between net photosynthesis and zero, and of potentially little value in ecological interpretation.

\section{NCP in Arctic cryoconite holes}

Measurements of NCP by the $\triangle \mathrm{CO}_{2}$ method should be robust, as it relies simply on changes in the chemistry of one bottle (the light bottle). The relatively small rates of NCP (mean of $-0.3 \mu \mathrm{g} \mathrm{Cg}^{-1} \mathrm{~d}^{-1}$, with a range of -11.9 to $8.0 \mu \mathrm{g}$ $\mathrm{Cg}^{-1} \mathrm{~d}^{-1}, \Delta \mathrm{CO}_{2}$ method; Table 2) reflect the close balance between rates of respiration and gross photosynthesis within incubation bottles. Many of the NCP measurements were close to the detection limit (Fig. 2), probably accounting for part of the large variation in NCP quotients (1.98 \pm 1.76$)$.

Previous estimates of NCP in Arctic cryoconite holes have been similarly low to those of the present study ( -0.6 to $-1.8 \mu \mathrm{g} \mathrm{Cg}^{-1} \mathrm{~d}^{-1}$; Table 3). Previous mean measurements of photosynthesis using the ${ }^{14} \mathrm{C}$ method have all been $<1.3 \mu \mathrm{g} \mathrm{Cg}^{-1} \mathrm{~d}^{-1}$ (Table 3). As discussed above, the ecological significance of the 24 hour ${ }^{14} \mathrm{C}$ data is uncertain; however, the low ${ }^{14} \mathrm{C}$ rates are consistent with a closely balanced or net heterotrophic ecosystem. This study therefore supports the conclusion that photosynthesis in cryoconite holes has at most a small, and more likely a negligible, impact on the net creation of organic matter, suggesting instead that organic matter may be derived largely from allochthonous sources (Stibal and others, 2008a; Hodson and others, 2010b). The major impact microbes can have in affecting the albedo of glaciers is then through the transformation and cementing together of allochthonous organic matter, rather than through the net creation of new dark organic matter (Hodson and others, 2010b).

\section{CONCLUSIONS}

This study compares different closed-bottle incubation methods of determining rates of gross photosynthesis, respiration and NCP in a range of cryoconite holes on three different valley glaciers in Svalbard. Rates of photosynthesis, respiration and NCP were determined by $\Delta \mathrm{O}_{2}$ and $\Delta \mathrm{CO}_{2}$ after 24 hour incubations. Rates of photosynthesis were also estimated using the ${ }^{14} \mathrm{C}$ method in parallel 24 hour incubations.

Rates of gross photosynthesis and respiration measured by the $\Delta \mathrm{CO}_{2}$ method were closely balanced (means of 17.3 and $20.1 \mu \mathrm{g} \mathrm{C} \mathrm{g}^{-1} \mathrm{~d}^{-1}$, respectively). The molar ratio of $\Delta \mathrm{O}_{2}: \Delta \mathrm{CO}_{2}$ in incubations gave mean respiratory and photosynthetic quotients of $0.80 \pm 0.17(1 \times \mathrm{SD})$ and $1.24 \pm 0.20(1 \times \mathrm{SD})$, respectively. The mean $\mathrm{NCP}\left(\Delta \mathrm{CO}_{2}\right.$ method) was just $-1.3 \mu \mathrm{g} \mathrm{Cg}^{-1} \mathrm{~d}^{-1}$, close to the detection limit, and consistent with previous very low measurements of NCP in cryoconite holes in Svalbard and Greenland. This indicates that NCP has a negligible impact on the net creation of organic matter in cryoconite holes, and suggests instead that organic matter may be derived largely from allochthonous sources (Stibal and others, 2008a; Hodson and others, 2010b).

Rates of photosynthesis estimated by the ${ }^{14} \mathrm{C}$ method were typically more than an order of magnitude lower than rates of gross photosynthesis estimated by the $\Delta \mathrm{CO}_{2}$ method and closer to (although not the same as) rates of NCP. 


\section{ACKNOWLEDGEMENTS}

This work was funded by grants awarded to A.A. and A.H. from the UK Natural Environmental Research Council (NERC) (NE/G00496X/1 and NE/G006253/1). We thank N. Cox for all his logistical support at the NERC Arctic Station, Ny-Ålesund. We also thank both the anonymous reviewers whose comments greatly improved the quality of this paper.

\section{REFERENCES}

Anesio, A.M., B. Mindl, J. Laybourn-Parry, A.J. Hodson and B. Sattler. 2007. Viral dynamics in cryoconite holes on a high Arctic glacier (Svalbard). J. Geophys. Res., 112(G4), G04S31. (10.1029/2006JG000350.)

Anesio, A.M., A.J. Hodson, A. Fritz, R. Psenner and B. Sattler. 2009. High microbial activity on glaciers: importance to the global carbon cycle. Global Change Biol., 15(4), 955-960.

Anesio, A.M. and 6 others. 2010. Carbon fluxes through bacterial communities on glacier surfaces. Ann Glaciol., 51(56) (see paper in this issue).

Baines, S.B. and M.L. Pace. 1991. The production of dissolved organic matter by phytoplankton and its importance to bacteria: patterns across marine and freshwater systems. Limnol. Oceanogr., 36(6), 1078-1090.

Behrenfeld, M.J. and P.G. Falkowski. 1997. A consumer's guide to phytoplankton primary productivity models. Limnol. Oceanogr., 42(7), 1479-1491.

Bender, M. and 12 others. 1987. A comparison of four methods for determining planktonic community production. Limnol. Oceanogr., 32(5), 1085-1098.

Billen, G. 1976. Evaluation of nitrifying activity in sediments by dark ${ }^{14}$ C-bicarbonate incorporation. Water Res., 10(1), 51-57.

Burris, J.E. 1977. Photosynthesis, photorespiration, and dark respiration in eight species of algae. Mar. Biol., 39(4), 371-379.

Christner, B.C., B.H. Kvito and J.N. Reeve. 2003. Molecular identification of bacteria and eukarya inhabiting an Antarctic cryoconite hole. Extremophiles, 7(3), 177-183.

Cullen, J.J., P.J. Neale and M.P. Lesser. 1992. Biological weighting function for the inhibition of phytoplankton photosynthesis by ultraviolet radiation. Science, 258(5082), 646-650.

De Smet, W.H. and E.A. van Rompu. 1994. Rotifera and Tardigrada from some cryoconite holes on a Spitsbergen (Svalbard) glacier. Belg. J. Zool., 124(1), 27-37.

Dring, M.J. and D.H. Jewson. 1982. What does ${ }^{14} \mathrm{C}$ uptake by phytoplankton really measure? A theoretical modelling approach. Proc. R. Soc. London, Ser. B, 214(1196), 351-368.

Ferreyra, G.A., S. Demers, P.A. del Giorgio and J.-P. Chanut. 1997. Physiological responses of natural plankton communities to ultraviolet-B radiation in Redberry Lake (Saskatchewan, Canada). Can. J. Fish. Aquat. Sci., 54(3), 705-714.

Fogg, G.E. 1983. The ecological significance of extracellular products of phytoplankton photosynthesis. Bot. Mar., 26(1), 3-14.

Furgal, J.A. and R.E.H. Smith. 1997. Ultraviolet radiation and photosynthesis by Georgian Bay phytoplankton of varying nutrient and photoadaptive status. Can. J. Fish. Aquat. Sci., 54(7), 1659-1667.

Gieskes, W.W.C., G.W. Kraay and M.A. Baars. 1979. Current ${ }^{14} \mathrm{C}$ methods for measuring primary production: gross underestimates in oceanic waters. Neth. J. Sea Res., 13(1), 58-78.

Gnaiger, E. 1983. Appendix C: calculation of energetic and biochemical equivalents of respiratory oxygen consumption. In Gnaiger, E. and H. Forstner, eds. Polargraphic oxygen sensors: aquatic and physiological applications. Berlin, etc., SpringerVerlag, 337-345.

Goto, N., T. Kawamura, O. Mitamura and H. Terai. 1999. Importance of extracellular organic carbon production in the total primary production by tidal-flat diatoms in comparison to phytoplankton. Mar. Ecol. Progr. Ser., 190, 289-295.

Herndl, G.J., G. Müller-Niklas and J. Frick. 1993. Major role of ultraviolet-B in controlling bacterioplankton growth in the surface layer of the ocean. Nature, 361(6414), 717-719.

Hobson, L.A., W.J. Morris and K.T. Pirquet. 1976. Theoretical and experimental analysis of the ${ }^{14} \mathrm{C}$ technique and its use in studies of primary production. J. Fish. Res. Board Can., 33(8), 1715-1721.

Hodson, A.J. and 10 others. 2007. A glacier respires: quantifying the distribution and respiration $\mathrm{CO}_{2}$ flux of cryoconite across an entire Arctic supraglacial ecosystem. J. Geophys. Res., 112(G4), G04S36. (10.1029/2007JG000452.)

Hodson, A. and 7 others. 2008. Glacial ecosystems. Ecol. Monogr., 78(1), 41-67.

Hodson, A.J. and 6 others. 2010a. The cryoconite ecosystem upon the Greenland Ice Sheet. Ann. Glaciol., 51(56) (see paper in this issue).

Hodson, A. and 6 others. 2010b. The structure, biological activity and biogeochemistry of cryoconite aggregates upon an Arctic valley glacier: Longyearbreen, Svalbard. J. Glaciol., 56(196), 349-362.

Kana, T.M. 1990. Light-dependent oxygen cycling measured by an oxygen-18 isotope dilution technique. Mar. Ecol. Progr. Ser., 64, 293-300.

Karl, D.M., D.V. Hebel, K. Björkman and R.M. Letelier. 1998. The role of dissolved organic matter release in the productivity of the oligotrophic North Pacific Ocean. Limnol. Oceanogr., 43(6), 1270-1286.

Lancelot, C. and S. Mathot. 1985. Biochemical fractionation of primary production by phytoplankton in Belgian coastal waters during short- and long-term incubations with ${ }^{14} \mathrm{C}$-bicarbonate. Mar. Biol., 86(3), 227-232.

Li, W.K.W. and P.M. Dickie. 1991. Light and dark ${ }^{14} \mathrm{C}$ uptake in dimly-lit oligotrophic waters: relation to bacterial activity. J. Plankton Res., 13, Suppl., s29-s44.

Li, W.K.W., B.D. Irwin and P.M. Dickie. 1993. Dark fixation of ${ }^{14} \mathrm{C}$ : variations related to biomass and productivity of phytoplankton and bacteria. Limnol. Oceanogr., 38(3), 483-494.

Morán, X.A.G., M. Estrada, J.M. Gasol and C. Pedrós-Alió. 2002. Dissolved primary production and the strength of phytoplankton-bacterioplankton coupling in contrasting marine region. Microbial Ecol., 44(3), 217-223.

Mueller, D.R. and W.F. Vincent. 2006. Microbial habitat dynamics and ablation control on the Ward Hunt Ice Shelf. Hydrol. Process., 20(4), 857-876.

Mueller, D.R., W.F. Vincent, W.H. Pollard and C.H. Fritsen. 2001. Glacial cryoconite ecosystems: a bipolar comparison of algal communities and habitats. In Elster, J., J. Seckbach, W.F. Vincent and O. Lhotský, eds. Proceedings of the International Conference on Algae and Extreme Environments: Ecology and Physiology, 11-16 September 2000, Téeboñ, Czech Republic. Berlin, J. Cramer/Stuttgart, Gebr. Borntraeger, 173-197. (Nova Hedwigia Beiheft 123.)

Peterson, B.J. 1980. Aquatic primary productivity and the ${ }^{14} \mathrm{C}-\mathrm{CO}_{2}$ method: a history of the productivity problem. Annu. Rev. Ecol. Syst., 11, 359-385.

Porazinska, D.L., A.G. Fountain, T.H. Nylen, M. Tranter, R.A. Virginia and D.H. Wall. 2004. The biodiversity and biogeochemistry of cryoconite holes from McMurdo Dry Valley glaciers, Antarctica. Arct. Antarct. Alp. Res., 36(1), 84-91.

Säwström, C., P. Mumford, W. Marshall, A. Hodson and J. Laybourn-Parry. 2002. The microbial communities and primary productivity of cryconite holes in an Arctic glacier (Svalbard $79^{\circ} \mathrm{N}$ ). Polar Biol., 25(8), 591-596.

Säwström, C., J. Laybourn-Parry, W. Granéli and A.M. Anesio. 2007a. Heterotrophic bacterial and viral dynamics in Arctic freshwaters: results from a field study and nutrient-temperature manipulation experiments. Polar Biol., 30(11), 1407-1415. 
Säwström, C., W. Granéli, J. Laybourn-Parry and A.M. Anesio. 2007b. High viral infection rates in Antarctic and Arctic bacterioplankton. Environ. Microbiol., 9(1), 250-255.

Stal, L.J. 2003. Microphytobenthos, their extracellular polymeric substances, and the morphogenesis of intertidal sediments. Geomicrobiol. J., 20(5), 463-478.

Steemann-Nielsen, E. 1952. The use of radioactive carbon $\left({ }^{14} \mathrm{C}\right)$ for measuring organic carbon production in the sea. J. Conseil Perm. Int. Explor. Mer, 18, 117-140.

Stibal, M. and M. Tranter. 2007. Laboratory investigation of inorganic carbon uptake by cryoconite debris from Werenskioldbreen, Svalbard. J. Geophys. Res., 112(G4), G04S33. (10.1029/2007JG000429.)

Stibal, M., M. Tranter, L.G. Benning and J. Rehák. 2008a. Microbial primary production on an Arctic glacier is insignificant in comparison with allochthonous organic carbon input. Environ. Microbiol., 10(8), 2172-2178.

Stibal, M., M. Tranter, J. Telling and L.G. Benning. 2008b. Speciation, phase association and potential bioavailability of phosphorus on a Svalbard glacier. Biogeochemistry, 90(1), $1-13$.

Takeuchi, N., S. Kohshima and K. Seko. 2001. Structure, formation, and darkening process of albedo-reducing material (cryoconite) on a Himalayan glacier: a granular algal mat growing on the glacier. Arct. Antarct. Alp. Res., 33(2), 115-122.

Thomson, B.E., H. Dyke and R.C. Worrest. 1980. Impact of UV-B radiation (290-320 nm) upon estuarine bacteria. Oecologia 47(1), 56-60.

Tranter, M. and 6 others. 2004. Extreme hydrochemical conditions in natural microcosms entombed within Antarctic ice. Hydrol. Process., 18(2), 379-387.

Williams, P.J.LeB. and D. Lefèvre. 2008. An assessment of the measurement of phytoplankton respiration rates from dark ${ }^{14} \mathrm{C}$ incubation. Limnol. Oceanogr. Meth., 6(1), 1-11.

Williams, P.J.LeB. and J.E. Robertson. 1991. Overall planktonic oxygen and carbon dioxide metabolisms: the problem of reconciling observations and calculations of photosynthetic quotients. J. Plankton Res., 13, Suppl., 153-169.

Yallop, M.L. 1982. Some effects of light on algal respiration and the validity of the light and dark bottle technique for measuring primary productivity. Freshwater Biol., 12(5), 427-433.

Yallop, M.L., B. de Winder, D.M. Paterson and L.J. Stal. 1994. Comparative structure, primary production and biogenic stabilization of cohesive and non-cohesive marine sediments inhabited by microphytobenthos. Estuar. Coast. Shelf Sci., 39(6), 565-582. 